\title{
Advices for Involving Parents in Children's Learning Activities from School to Home
}

\author{
Alfiana Falan Syarri Auliya1, Puji Yanti Fauziah ${ }^{2}$ \\ Pendidikan Anak Usia Dini, Universitas Negeri Yogyakarta (1) \\ Pendidikan Luar Sekolah, Universitas Negeri Yogyakarta (2) \\ DOI: $\underline{10.31004 / \text { obsesi.v5i2.621 }}$
}

\begin{abstract}
Parental involvement in children's learning activities is important for the optimal of their growth and development. The aims of writing this library research article is to provide advices that can be applied in early childhood education institutions in terms of involving parents in children's learning activities at home. In this research, several topics related to parental involvement are explained, including factors that influence and the type of parental involvement, forms of parental involvement in children's learning and advices for involving parents in children's learning activities. This article used the literature review method and the data analysis used was descriptive. In short, this article is expected to help educators find strategies for involving parents to continue children's learning activities from school to home. Then, it is recommended for educators to use the results of this study, which is advices for involving parent in children's learning activities. Every parent must accompany the child's learning activities so that learning activities run effectively and can optimize the child's growth and development.
\end{abstract}

Keywords: parental involvement; learning; early childhood.

\begin{abstract}
Abstrak
Keterlibatan orang tua dalam kegiatan belajar anak merupakan hal yang penting bagi optimalnya tumbuh kembang anak. Penulisan artikel library research ini bertujuan untuk memberikan rekomendasi saran dalam hal melibatkan orang tua pada kegiatan belajar anak di rumah yang dapat diterapkan di satuan pendidikan anak usia dini. Dalam penelitian ini dijelaskan topik-topik yang berkaitan dengan keterlibatan orang tua yang meliputi faktor yang mempengaruhi, jenis keterlibatan, bentuk keterlibatan, dan saran untuk melibatkan orang tua dalam kegiatan pembelajaran anak. Metode penelitian menggunakan kajian pustaka dengan teknik analisis deskriptif. Secara singkat, artikel ini diharapkan dapat membantu pendidik dalam menemukan strategi pelibatan orang tua untuk melanjutkan kegiatan pembelajaran anak dari sekolah ke rumah. Kemudian direkomendasikan bagi pendidik menggunakan hasil kajian ini yaitu berupa saran-saran untuk melibatkan orang tua dalam kegiatan pembelajaran anak. Setiap orang tua harus mendampingi kegiatan belajar sehingga dapat berjalan efektif dan mampu mengoptimalkan tumbuh kembang anak.
\end{abstract}

Kata Kunci: pelibatan orang tua; belajar; anak usia dini.

Copyright (c) 2020 Alfiana Falan Syarri Auliya, Puji Yanti Fauziah

$\triangle$ Corresponding author:

Email Address : alfiana.auliya@gmail.com (Klaten, Jawa Tengah)

Received 28 Juni 2020, Accepted 28 September 2020, Published 3 Oktober 2020 


\section{INTRODUCTION}

The success of children's education is basically very dependent on the involvement of parents as members of the community because parents are the first and the main educational institution for children (Adhe et al., 2021: 294). In addition, parents also play the role of primary educators who need to realize that children spend more time at home than at school. This argument is supported by Law of the Republic of Indonesia Number 20 of 2003 concerning Chapter XV National Education System Article 54 (Undang-Undang Republik Indonesia Nomor 20 tahun 2003 tentang Sistem Pendidikan Nasional Bab XV Pasal 54) which explains that, "community participation in education includes the participation of individuals, groups, parents, professional organizations, entrepreneurs, and social organizations in organizing and controlling the quality of educational services." Therefore, it is important to build a bridge between teachers and parents in the education of children by involving the parents in children's education so that there are no gaps between teachers and parents in the education of children carried out at school with those at home (Rohmawati, 2015: 19). The problem related to the involvement of parents in learning at home recently highlighted is the obstacle of parents in assisting children to learn at home during the Covid-19 pandemic because the government has issued a learning policy at home (learn from home) as a step to anticipate the virus spread (Wiresti, 2021: 647).

A news posted on the Republika's website (Saubani, 2020) explained the results of interviews related to the problems of parents in assisting children to learn at home that, although it looks fun, but in reality watching the child's learning process while at home is not easy to do. Problems that arise related to this include: difficulties in how to discipline time, stressed parents, inability of parents to facilitate children's learning media, lots of learning material, and teacher readiness in implementing online learning. In line with the news article on the Republika, a research conducted by Wardani dan Ayriza (2021: 773-774), it is explained about some of the learning problems at home that originate being told by 12 parents who have children attending kindergarten, namely that, for parents who are accustomed to submitting matters of teaching and learning activities of children at school, it is not easy for them to take the role of the teacher at home, especially in foster interest in learning and dividing time. Actually, the problems related to assisting parents in learning children when at home have existed since before the pandemic. This is especially true in terms of parental involvement to continue learning from school to home.

A research conducted by Agustin et al shows various obstacles related to the involvement of parents in the learning activities of Playgroup, Kindergarten and RA children ages during the Covid-19 pandemic. It was explained that out of 645 teachers in West Java who were the research samples, as many as $41,8 \%$ stated often in terms of difficulty finding common thoughts with parents about children's learning goals and $35.1 \%$ teachers stated that often in terms of obstacles to getting actual information on children's activities at home, this problem refers to communication obstacles between the school and parents (Agustin et al., 2021: 337). In line with the research before the pandemic conducted by Irma, Nisa, and Sururiyah (2019:220) in TK Masyithoh 1 Purworejo also mentioned about some issues related to parent involvement in continuing children's learning activities from school to home including the following: (1) limitations of parental education; (2) parents' income; (3) family type; (4) the stage of parental experience in children's education; and (4) role models applied in the family. Apart from that, the research also showed that the problems related to the involvement of parents in children's learning activities are, that some parents are busy for working so that they do not have the time to review the learning materials that children get at school. In addition, the lack of parental knowledge on the material taught causes parents to assume this is the responsibility of the teacher (Irma et.al., 2019:215). Research in the field showed that parents have not been able to become facilitators and motivators of children while studying at home where this is evidenced by parents calling private tutors to learn to read, 
write, count and learn foreign languages or to simply help with homework at home (Amini, 2015:17).

One of the efforts made by the government to overcome this problem is by giving assignments to each education unit to encourage the involvement of parents in helping children's learning activities at home, such as providing facilities and creating a supportive atmosphere (Rihatno et al., 2017:117). Research conducted by Desforges and Aboucgaar in Harris and Goodall (2008:279) found that parental involvement in learning at home throughout the age range had a significant influence on educational achievement at the next level. The most effective type of family involvement comes from studying at home (Sharon in Graham, 2010:8). In this case, it does not mean parents are taught or children are given a lot of homework, but rather leads to conversations that show the value of education, promote high expectations and shared aspirations between children, parents and schools.

Hill and Taylor in Punter et al., (2016:5) explained that parental involvement is a term used to represent the interaction of parents with the school and with their children in an effort to support academic success which includes various behaviors and activities of parents that are directly or indirectly related to their children's education. The terms school-home involvement and partnership are often used to describe parents' investment in their child's education. Parental involvement is a measure of the level to parental behavior participates in various aspects of a child's life (Finley in Indrasari and Affiani 2018:76). However, the term parental involvement in this case is intended to summarize the types of participation that are most likely to produce positive results for the development of their children (Hodges dan Healy, 2017:252). Active parental participation covers all aspects of social, emotional and academic development. In addition, parental participation in this case also includes parental aspirations related to children's education, children's future plans, children's educational decision making, parental support for schoolwork, parental knowledge and participation in schools (Castro et al., 2015: 34; Kaplan Toren \& Seginer, 2015: 812).

There are several factors that influence parental involvement, both inhibiting and supporting. The factors are as follows (Diadha, 2015:67-68): (1) individual parent factors which include parental perceptions of the importance of involvement in children's education and invitations to be involved as well as parental background; (2) child factors in the form of conditions and behavior of children; (3) parent and teacher factors including language, purpose of involvement and attitudes of parents and teachers; and (4) social factors which include the history, demographics, politics and economics of parents. In addition to the general factors that influence parental involvement, there are also factors that specifically influence parental involvement in children's learning. The main barriers that are identified so that parents can effectively support their children's learning are learning languages and schools (Butler, 2010: 11). Parents who do not understand the language of learning will have difficulty contributing to children's learning activities. Therefore, to overcome this they need to be involved in school and in children's learning at home. While the most significant driving factor of parental involvement is regular communication between teachers and parents (Putri et.al., 2020:717).

Parents can support child educators by providing information about their children that can help identify goals and strategies that are useful for planning learning activities. Communicate about ways of working with children and their development goals is an important thing to do for parents and their children educators. Consistency in guiding children's behavior between at home and at school is an effective effort in parental intervention programs. By implementing an effective family behavioral intervention program to inform early childhood learning settings will benefit both parents and schools (Turner, et.al., 2017:244249). Regard to the role of parental support for homework, it's widely assumed that parent's help will have a positive effect on learning activities and academic achievement (Punter et.al., 2016:8). Involvement that requires a lot of time and is mild has a greater impact on student education outcomes than more traditional or demonstrative forms of engagement (Jaynes in 
Latunde, 2017:10). Although parental involvement consists of many aspects, the researchers agree that parenting is "good at home" and participation in children's learning at home is a place and opportunity for parents to be able to make the greatest contribution to their child's development (Desforges and Abouchaar, Harris and Goodall, Hattie and Perkins in Hodges and Healy, 2017:253).

The description above shows the importance of parental involvement in children's learning activities, so with this library research, researchers want to find solutions to overcome problems that arise related to parental involvement in children's learning activities through literature analysis of the latest literature. This study aims to provide recommendations in terms of involving parents in children's learning activities at home that can be applied in early childhood education units. From the results of this study, it is hoped that the teacher can find the most appropriate way to involve parents of early childhood in learning activities based on the needs, conditions and abilities of the parties involved. It is hoped that after applying the research results, the involvement of parents in learning activities for children at the age of KB and TK / RA, especially in continuing activities from school to home can run more optimally. The results of this study are not limited to the Covid-19 pandemic.

\section{METHODOLOGY}

In this library research, the literature review methodology was used. Literature review is a systematic examination of scientific literature on a topic which then critically analyzed, evaluated, and synthesized research findings, theories, and practices from researchers related to the chosen topic (Efron and Ruth, 2019:3). Literature study in this study was conducted by reviewing the latest literature such as journals, research, books and other literature relating to the involvement of parents in children's learning activities where data analysis is done descriptively. The author seeks to provide suggestions that can be used by educators to involve parents in continuing learning activities from school to home. The methodology is illustrated in Figure 1

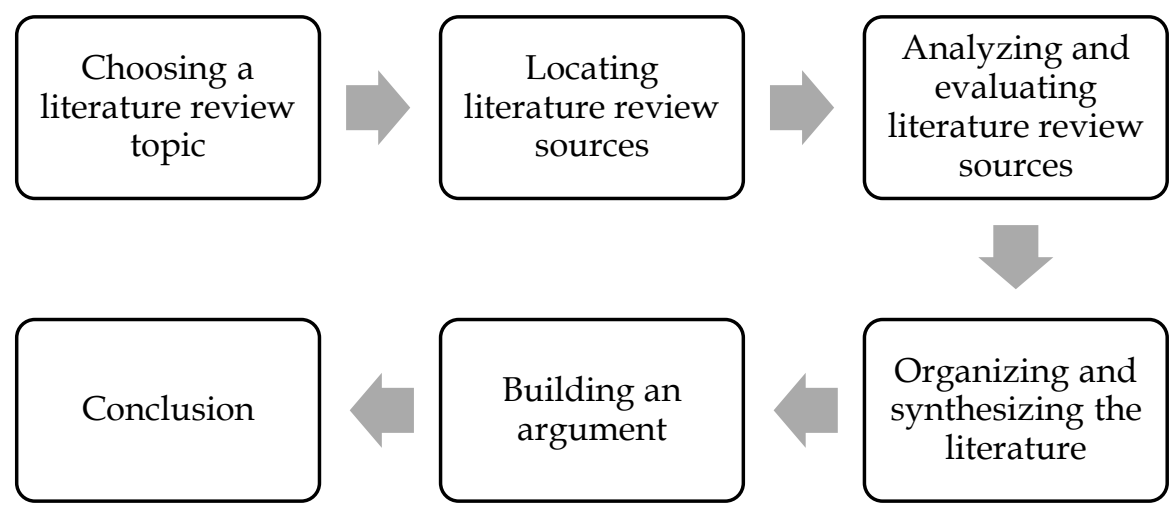

Figure 1 The Steps on Literature Review

The purpose of this study was to describe various strategies that can be applied to involve parents in continuing children's learning activities from school to home. This research attempts to answer the following questions: (1) What is the meaning of parental involvement? (2) What factors influence parental involvement? (3) What are the types of parental involvement? (4) What is the ideal form of parental involvement in children's learning activities? (5) What should the teachers do before involving or building partnership with parents? (6) What suggestions can be applied to involve parents in continuing children's learning from school to home? The answers to questions number one through three have been explained in the literature review. Meanwhile the answers to the three last questions will be explained in the results section. 


\section{RESULTS AND DISCUSSION}

The success of learning activities in continuing learning activities from school to house in early childhood cannot be separated from the role of parents. The right form of parental involvement is chosen based on the needs, conditions and abilities of the parties involved. Fantuzzo et.al., in Sheridan and Kim (2015:3) divide the types of parent involvement in children's education into two, namely school based involvement and home based involvement. School-based involvement is the involvement of parents at school, for example by being involved in school committees, attending parent-teacher meetings, or volunteering at school. Meanwhile, home-based involvement is intended for various activities at home such as talking to children about activities at school, helping children do homework, read together with children or bring children to the library. There are various engagement models that can be applied by schools, but the partnership model is considered the most appropriate to apply. Turnbull et.al., in Hornby (2011:30-31) explained the seven principles of effective partnership between educators and parents, namely long-term commitment in various activities, building trust in relationships, engaging together in problem solving, planning, and decision making, as well as advocacy, mutual respect, trusting educators' competencies, and conducting twoway communication. During the Covid-19 pandemic, where learning activities were carried out at home, the choice to implement home-based involvement with the right activities could be a solution for involving parents in children's learning activities.

Home based in the type of involvement according to Epstein (2011:487-488) means involving families with their children in home learning activities, including homework and other activities and decisions related to the school curriculum. The key dimensions of connecting learning at home and at school emphasize the importance of understanding in family and school (Emerson at.al., 2012:28), which are as follows: (1) overlapping between the home and school environment; (2) the formation of successful partnership relationships in children's learning, including the importance of high expectations from teachers and parents for the success of children in school; (3) the importance of families and schools to work together in an effort to create positive attitudes towards learning, and parents who work with teachers in the educational decision making process for their children; (4) the benefits of schools being a place and agent for parents' self-development, learning and developing new skills. Parents involvement in children's learning activities at home is done through accompany children to read, the provision of a home environment that can stimulate children's development, do activities at home together, provide learning resources and learning activities at home such as books, music, and discuss about daily activities every day, giving guidance and support to children to do homework, play games together, and make crafts (Hayes et.al., 2016:3-5; Jay et.al., 2018:2; and Williams and Williams, 2019:4).

Before establishing a partnership with parents of children in relation to continuing learning activities from school to home, understanding the strategies for involving parents in appropriate learning activities is an important thing to do. Various problems that arise related to the assistance of parents in children's learning activities is an evidence that a strategy must be thought through carefully. This step requires more efforts in developing forms of communication between school and parents and involves drastic changes, especially in assumptions about how to work with parents and the application of appropriate strategies in parent involvement (Hornby, 2000: 151). Some things that must be considered when communicating with parents include (Mariconda, 2003: 13): focuses on the main objectives, namely helping children; providing information; building an atmosphere of communication that is directed, intimate, consistent, sensitive to individual circumstances; carried out objectively, lovingly, and in a professional manner. Giving a "friendly impression" to parents before communicating will reflect appreciation by the teacher. There are two types of communication directions involved, namely one-way communication where teachers provide information to parents about various children's activities and two-way communication where teachers and parents have a dialogue about matters relating to children (Graham-clay, 2005: 
118-121). Good communication between teachers and parents will increase the success of involving parents in children's learning activities. Here are some suggestions that can be applied by educators to involve parents in continuing children's learning activities from school to home.

\section{Hold a discussion session with parents}

Discussing with parents is an effective way to involve parents in children's learning at home. Through discussion, parents will feel the need to help children at home, so they will better understand what children have learned during (Yotyodying \& Wild, 2019:2). Discussions can be done by holding meetings with parents in their homes to talk about ways parents can support children's learning at home, children's learning problems while at school, and learning approaches used in class. Meetings can also be held at school by asking parents to be directly involved, respecting cultural differences in the classroom, and considering the situation at home and creating a philosophy of partnership where student success is seen as collaboration between stakeholders (Henderson and Mapp in Prakter \& Chen, 2013: 356). In addition, better understand that discussion can build trust and collaborative relationships between teachers and children's families, especially parents.

During the Covid-19 pandemic situation, discussing with parents through home visits may be difficult. Especially with the recognition of the policy of limiting visits and social distancing by the government (Wardani \& Ayriza, 2021: 773). Another obstacle that may arise is the cost for home visits and the length of time it takes to visit one child's house to another with the large number of students and the limited number of teachers. In this situation it would be difficult to make home visits by teachers or gather at school for discussions. However, this should not be a barrier to discussion with parents. Teachers are required to use a creative approach. The use of Information and Communication Technology (ICT), especially internetbased as a means of communication for example with whatssapp group, zoom, and other applications can be a solution. Beside the home visit, Hornby (Hornby, 2000:33) explained that there are 4 ways that can be used for interactive dialogue with parents, namely through parent teacher meetings, telephone contacts (either parents phoning teachers or teachers phoning parents), informal contacts, and various forms of written communication.

\section{Build relationships through interactive home-based tasks}

When parents and children collaborate on interactive tasks, children will learn while they spend quality time with their parents (Perkins, 2014:8). The learning assignment arranged based on the ability of parents and the needs of children so as not to make parents feel burdened. The intended interactive task can take the form of a collaborative project between parents and school staff that integrates learning at home and school, which can be in showing the children's learning outcomes at school, sharing or discussing ideas with parents, and showing the skills that have been learned.

Educators need to be aware if homework assignments can be emotionally burdensome. In addition, parents also need to be aware of the 'vicious circle' which has the potential to increase negative emotions and the detrimental effect of excessive involvement (Silinskas et.al., 2015:431). Therefore, educators need to understand the ways to get parental support without disturbing the atmosphere in the family. Related to this, the type of homework given from schools must be followed up by parents if they want results in the form of positive influences (Kraft dan Rogers, 2015:50). The type of homework referred to the homework that can cause pleasant, loving, and supportive interactions, so that the positive effects caused can create a feeling of comfort (connected) which will thus increase learning motivation and fun for children. 
DOI: 10.31004 /obsesi.v5i2.621

\section{Utilizing social media}

The use of social media as a medium for all communication needed between home and school from the first day of school can be applied by schools. Teachers involve parents as teacher assistants by providing various information (Sparrman et,al., 2016:92-98). Social media can be used as a means to inform parents and involve them in their children's education at school. Things that can be informed include asked the parents to help their children's work. Every once a week, the teacher informs parents about a "weekly work schedule", which consists of a detailed weekly plan on activities at school for the next week, assignments given as well as books or recommended media and links to educational sites for parent reference to continue stimulation for the children.

\section{Compiling the comprehensive curriculum}

The most effective family involvement strategy is a strategy that leads to learning at home, one of which is by providing assistance to parents to overcome the barriers of involvement which if not resolved will limit the effectiveness of parental learning support, the barriers described as "learning languages". In this case, creating a comprehensive curriculum for parents can be applied as a means (Sharon in Graham, 2010:8). These efforts made to show recognition and respect to parents' contribution in their children's learning. Parents and school staff together develop plans and collaborate with agreed collaborative projects that lead to the integration of learning between home and school (Joni in Graham, 2010:9). In addition, parents and their children also need to be involved in all decisions related to the school curriculum.

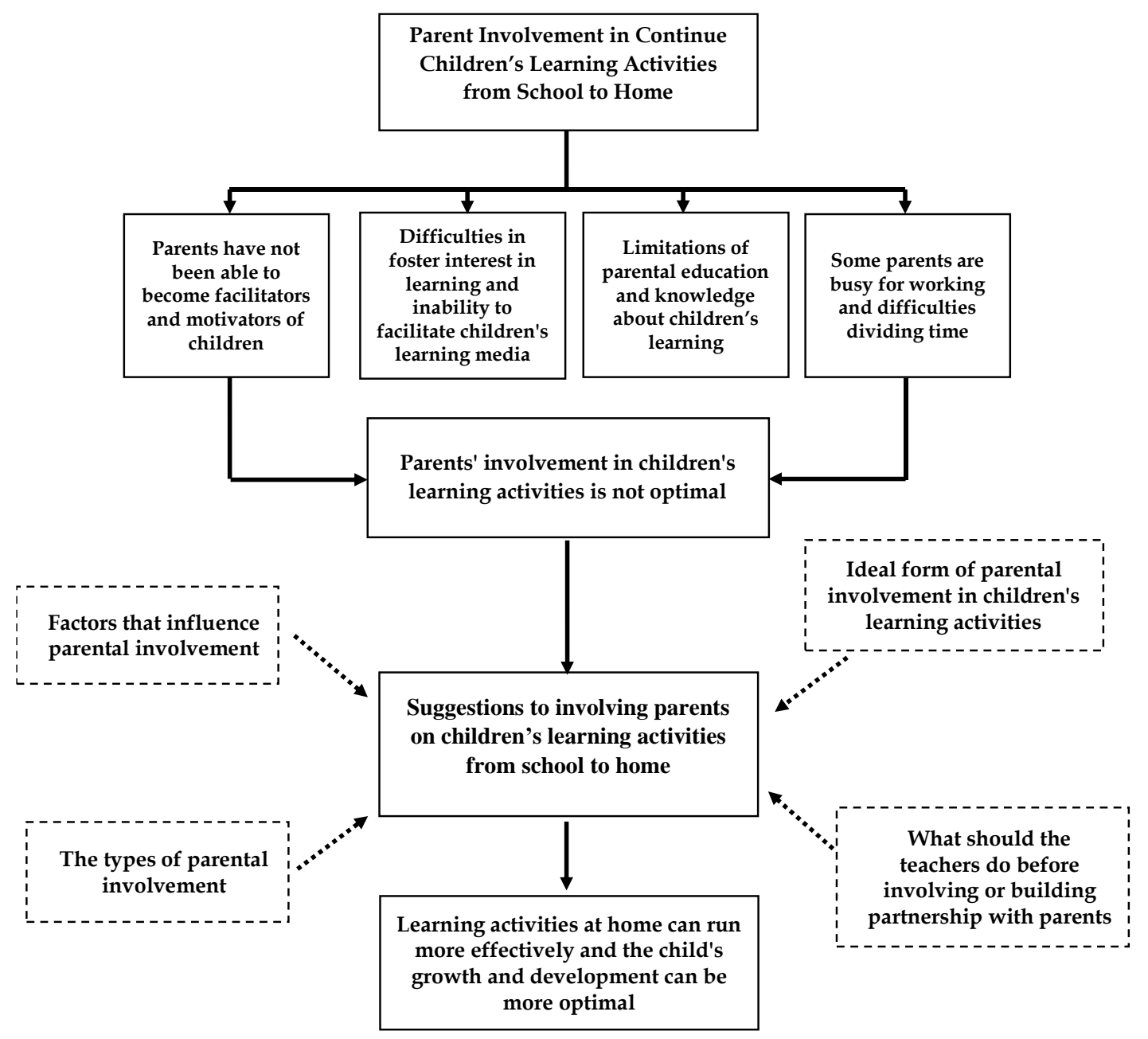

Figure 2. Scheme Chart Involving Parents in Children's Learning Activities 


\section{CONCLUSION}

Parent involvement is interpreted as parental interaction with schools and children which includes various behaviors and activities of parents that are related to their child's education. Involving parents in children's learning activities by continuing learning from school to home is one form of effective involvement. There are several suggestions that educators and schools can implement to involve parents, namely by hold a discussion session, facilitating collaboration between teachers and parents, building relationships through interactive home-based tasks, utilizing social media and compiling a comprehensive curriculum. Parents must accompany children's learning activities so that learning activities at home can run more effectively.

\section{ACKNOWLEDGEMENT}

I would like to thanks to thanks to the grace of Allah SWT, the writer can complete this article to completion, thanks to the precursor researchers who have done the research and willing to share their knowledge and research result to be developed. The researcher also thanked to the lecturer of Yogyakarta State University and Jurnal Obsesi editorial team so the journal was decent for publication.

\section{REFERENCES}

Adhe, K. R., Maulidiya, R., Arif, M., Ardha, A., \& Patria, W. (2021). Learning During the Covid19 Pandemic: Correlation Between Income Levels And Parental Roles. Jurnal Obsesi : Jurnal Pendidikan Anak Usia Dini, 5(1), 293-302. https:// doi.org/10.31004/obsesi.v5i1.554

Agustin, M., Puspita, R. D., Nurinten, D., \& Nafiqoh, H. (2021). Tipikal Kendala Guru PAUD dalam Mengajar pada Masa Pandemi Covid 19 dan Implikasinya. Jurnal Obsesi : Jurnal Pendidikan Anak Usia Dini, 5(1), 334-345. https:/ / doi.org/10.31004/obsesi.v5i1.598

Amini, M. (2015). Profil Keterlibatan Orang Tua dalam Pendidikan Anak Usia TK. Jurnal Ilmiah VISI PPTK PAUDNI, 10(1), 9-20. https:/ / doi.org/10.21009/JIV.1001.2.

Butler, S. (2010). Family-School Partnerships Make a Difference. In N. Barnard (Ed.), Partnership with Parents (Vol. 8). Abbotsford: Professional Voice.

Castro, M., Expósito-Casas, E., López-Martín, E., Lizasoain, L., Navarro-Asencio, E., \& Gaviria, J. L. (2015). Parental involvement on student academic achievement: A meta-analysis. Educational Research Review, 14, 33-46. https://doi.org/10.1016/j.edurev.2015.01.002

Diadha, R. (2015). Keterlibatan Orang Tua dalam Pendidikan Anak Usia Dini di Taman KanakKanak. Jurnal Ilmu Pendidikan dan Pengajaran, 2(1), 61-71. https:// doi.org/https:// doi.org/10.17509/edusentris.v2i1.161

Efron, S. E., \& Ruth, D. (2019). Writing The Literature Review: A Practical Guide. New York: The Guilford Press.

Emerson, L., Fear, J., Fox, S., \& Sanders, E. (2012). Parental engagement in learning and schooling: Lessons from research. Family-School and Community Partnerships Bureau. Canberra: Australian Research Alliance for Children \& Youth.

Epstein, J. L. (2011). School, Family and Community Partnerships: Preparing Educators and Improving Schools (2 ed.). Boulder: Westview Press.

Graham-clay, S. (2005). Communicating with Parents: Strategies for Teachers. The School Community Journal, 15(1), 117-130.

Graham, J. (2010). Families and Schools-The Learning Partnership. In N. Barnard (Ed.), Personal Voice (Vol. 8, hal. 7-10). Abbotsford: The Australian Education Union Victorian Branch.

Harris, A., \& Goodall, J. (2008). Do parents know they matter? Engaging all parents in learning. Educational Research, 50(3), 277-289. https:// doi.org/10.1080/00131880802309424 
DOI: 10.31004/obsesi.v5i2.621

Hayes, N., Berthelsen, D. C., Nicholson, J. M., \& Walker, S. (2016). Trajectories of parental involvement in home learning activities across the early years : associations with sociodemographic characteristics and children's learning outcomes. Early Child Development and Care, 1-14. https:/ / doi.org/10.1080/03004430.2016.1262362

Hodges, J., \& Healy, K. L. (2017). Parenting Support and the School System. In M. R. Sanders \& T. G. Mazzuchelli (Ed.), The Power of Positive Parenting. New York: Oxford University Press. https://doi.org/10.1093/med-psych/9780190629069.003.0022

Hornby, G. (2000). Improving Parental Involvement. London: Continuum.

Hornby, G. (2011). Parental Involvement in Childhood Education: Building Effective SchoolFamily Partnerships. In Parental Involvement in Childhood Education (hal. 1-49). New York, NY: Springer New York. https://doi.org/10.1007/978-1-4419-8379-4_1

Indrasari, S. Y., \& Affiani, L. (2018). Peran Persepsi Keterlibatan Orang Tua dan Strategi Pengasuhan Terhadap Parenting Self-Efficiacy. Jurnal Psikologi Sosial, 16(02), 74-85. https://doi.org/10.7454/jps.2018.8

Irma, C. N., Nisa, K., \& Sururiyah, S. K. (2019). Keterlibatan Orang Tua dalam Pendidikan Anak Usia Dini di TK Masyithoh 1 Purworejo. Jurnal Obsesi : Jurnal Pendidikan Anak Usia Dini, 3(1), 214-224. https:// doi.org/10.31004/obsesi.v3i1.152

Jay, T., Rose, J., \& Simmons, B. (2018). Why Is Parental Involvement in Children's Mathematics Learning Hard? Parental Perspectives on Their Role Supporting Children's Learning. SAGE Open, 1-13. https:/ / doi.org/10.1177/2158244018775466

Kaplan Toren, N., \& Seginer, R. (2015). Classroom climate, parental educational involvement, and student school functioning in early adolescence: a longitudinal study. Social Psychology of Education, 18(4), 811-827. https:/ / doi.org/10.1007/s11218-015-9316-8

Kraft, M. A., \& Rogers, T. (2015). The underutilized potential of teacher-to-parent communication: Evidence from a field experiment. Economics of Education Review, 47, 49-63. https://doi.org/10.1016/j.econedurev.2015.04.001

Latunde, Y. C. (2017). Research in Parental Involvement. (R. Nokkoul, Ed.) (Vol. 1). New York: Palgrave Macmillan US. https:/ / doi.org/10.1057/978-1-137-59146-3

Mariconda, B. (2003). Easy and Effective Ways to Communicate with Parents. New York: Scholastic Professional Books.

Perkins, K. (2014). Parents and teachers: Working together to foster children's learning. The Research Digest, (10), 1-19. https:/ / doi.org/https:/ / doi.org/10.2307/42915534

Prakter, A., \& Chen, L. (2013). The Daily Text: Increasing Parental Involvement in Education With Mobile. Journal of Educational Technology Systems, 41(4), 353-367. https://doi.org/http://dx.doi.org/10.2190/ET.41.4.f

Punter, R. A., Glas, C. A. W., \& Meelissen, M. R. M. (2016). Psychometric Framework for Modeling Parental Involvement and Reading Literacy. International Association for the Evaluation of Educational Achievement. Overijssel: Springer Open. https://doi.org/10.1007/978-3319-28064-6 ISSN

Putri, D. K., Handayani, M. C., \& Akbar, Z. (2020). Pengaruh Media Pembelajaran dan Motivasi Diri terhadap Keterlibatan Orang Tua dalam Pendidikan Anak Abstrak. Jurnal Obsesi: Jurnal Pendidikan Anak Usia Dini, 4(2), 649-657. https://doi.org/10.31004/obsesi.v4i2.418

Rihatno, T., Yufiarti, Y., \& Nuraini, S. (2017). Pengembangan Model Kemitraan Sekolah dan Keluarga pada Pendidikan Anak Usia Dini. Jurnal Pendidikan Anak Usia Dini, 11(4), 117129. https:/ / doi.org/https:/ / doi.org/10.21009/JPUD.111

Rohmawati, A. (2015). Efektivitas Pembelajaran. Jurnal Pendidikan Usia Dini, 9(1), 15-32. https://doi.org/https://doi.org/10.21009/JPUD.091.02

Saubani, A. (2020, March 18). Murid Belajar di Rumah: Stres Orang Tua dan Kendala Lainnya. Republika.co.id. Retrieved from https://republika.co.id/berita/q7dlrn409/muridbelajar-di-rumah-stres-orang-tua-dan-kendala-lainnya

Sheridan, S. M., \& Kim, E. M. (2015). Family-school partnerships in context. Family-School 
Partnerships in Context. https:// doi.org/10.1007/978-3-319-19228-4

Silinskas, G., Kiuru, N., Aunola, K., Lerkkanen, M., \& Nurmi, J. (2015). The Developmental Dynamics of Children's Academic Performance and Mothers' Homework-Related Affect and Practices. Developmental Psychology, 51(4), 419-433. https://doi.org/http://dx.doi.org/10.1037/a0038908

Sparrman, A., Westerling, A., Lind, J., \& Dannesboe, K. I. (2016). Doing Good Parenthood: Ideals and Practices of Parental Involvement. Switzerland: Palgrave Macmillan US. https:// doi.org/10.1007/978-3-319-46774-0

Turner, K. M. T., Dittman, C. K., Rusby, J. C., \& Lee, S. (2017). Parenting Support in an Early Childhood Learning Context. In M. R. Sanders \& T. G. Mazzuchelli (Ed.), The Power of Positive Parenting. New York: Oxford University Press. https://doi.org/10.1093/medpsych/9780190629069.003.0021

Wardani, A., \& Ayriza, Y. (2021). Analisis Kendala Orang Tua dalam Mendampingi Anak Belajar di Rumah Pada Masa Pandemi Covid-19. Jurnal Obsesi : Jurnal Pendidikan Anak Usia Dini, 5(1), 772-782. https:// doi.org/10.31004/obsesi.v5i1.705

Williams, K., \& Williams, H. (2019). Mathematics problem-solving homework as a conduit for parental involvement in learning: Evaluation of a pilot. Educational Review, 1-21. https:// doi.org/10.1080/00131911.2019.1566210

Wiresti, R. D. (2021). Analisis Dampak Work From Home pada Anak Usia Dini di. Jurnal Obsesi: Jurnal Pendidikan Anak Usia Dini, 5(1), 641-653. https:// doi.org/10.31004/obsesi.v5i1.563

Yotyodying, S., \& Wild, E. (2019). Effective family - school communication for students with learning disabilities: Associations with parental involvement at home and in school. Learning, Culture and Social Interaction, 22, 1-12. https://doi.org/10.1016/j.lcsi.2019.100317 